\title{
DESAIN SARANA KERJA MENJAHIT
}

\author{
Darius Shyafari \\ Staf Pengajar Program Studi Desain Produk, Jurusan Desain \\ Politeknik Negeri Samarinda \\ e-mail: dariusshyafari@gmail.com \\ Ameliya Mamesah \\ Mahasiswa Program Studi Desain Produk, Jurusan Desain \\ Politeknik Negeri Samarinda
}

\begin{abstract}
Abstrak
Menjahit merupakan sebuah kerajinan tangan yang menggunakan jarum dan benang untuk mengikat sesuatu atau menyambungkan sesuatu, akan tetapi agar kegiatan menjahit menjadi lebih mudah tentunya ada beberapa persiapan yang harus direncanakan secara matang seperti mempersiapkan peralatan menjahit secara lengkap, menyediakan sarana atau tempat membuat pola, memotong pola, menyetrika kain yang menyediakan kebutuhan penjahit dalam bekerja secara lengkap sehingga penulis ingin mendesain "Desain Sarana Kerja Menjahit" yang dapat meringankan pekerjaan penjahit. Metode perancangan yang dilakukan yaitu dengan melakukan pengumpulan data, analisis data, menentukan konsep desain, membuat desain alternatif, mengembangkan desain alternatif, mengembangkan desain alternatif, hingga desain akhir. Untuk itu, dengan adanya "Desain Sarana Kerja Menjahit" pengguna dapat melakukan aktivitas menjahit secara mudah dengan desain yang lebih ergonomis, dan estetis yang bernuansa modern dilengkapi dengan konfigurasi yang teratur dan rapi, serta mengutamakan kenyamanan dan keamanan bagi pengguna sehingga semua dapat terakomodir dalam satu produk.
\end{abstract}

Kata kunci : Menjahit, modern, peralatan menjahit.

\begin{abstract}
Sewing is a handicraft that uses needles and threads to tie something or connect something, but for sewing activities to be easier there must be some preparations that must be carefully planned such as preparing complete sewing equipment, providing a means or place to make patterns, cut patterns, ironing stitched fabrics, and a special table for sewing. Currently there is still no product that provides tailor needs in complete work so that the author wants to design "Sewing desing Working Facility" which can ease the tailor's work. Designing method is done by doing data, data analysis, determine the design concept, create alternative design, develop alternative design, develop alternative design, until the final design. For that purpose, with "Sewing Working Facility" users can easily tailor activities with a more ergonomic design, and the aesthetically modern nuances are equipped with a neat and orderly configuration, and give priority to the comfort and safety of the users so that all can be accommodated in one product.
\end{abstract}

Keywords: Sewing, modern, sewing equipment. 
Darius Shyafari, Ameliya Mamesah, Desain Sarana Kerja Menjahit

\section{Pendahuluan}

Menurut Winsen (2016) menjahit merupakan sebuah kerajinan tangan yang menggunakan jarum dan benang untuk mengikat sesuatu atau menyambungkan sesuatu, umumnya penjahit lebih sering menggunakan mesin jahit, mesin itu terbagi menjadi dua yaitu tradisional/manual dan elektrik. Sebanyak $79 \%$ orang lebih berminat untuk menjahit pakaian sendiri dibanding harus membeli pakaian jadi dengan beberapa alasan seperti, ukuran yang susah dicari, pola pakaian jadi yang kurang nyaman dan lebih memilih menjahit pakaian ke penjahit pada acara tertentu agar dapat mengekspresikan diri dengan model pakaian yang ingin dibuat, sedangkan $21 \%$ orang mengaku bahwa membeli pakaian jadi lebih praktis dibanding harus pergi ke penjahit karena biaya menjahit lebih mahal. Dari sini dapat disimpulkan bahwa pekerjaan menjahit memang sangat dibutuhkan, terbukti dengan hasil presentasi yang jauh lebih tinggi.

Peralatan-peralatan yang diperlukan penjahit cukup banyak seperti benang, gunting, jarum, busa pundak, resleting, karet, kancing, skoci, kain lapis, meteran dan yang paling penting adalah mesin jahit. Ada juga alat-alat pendukung dalam menjahit seperti meja, alat setrika dan rak penyimpanan. Akan tetapi hasil kuisioner merangkum bahwa alat yang paling sering digunakan seorang penjahit adalah jarum dengan presentasi $86,6 \%$, gunting $83,3 \%$, benang $83,3 \%$, meteran $40 \%$, penggaris $26,6 \%$, kancing $23 \%$, resleting $16,6 \%$ dan lain sebagainya yang hasil presentasinya jauh lebih rendah.

Melalui survey dan wawancara yang terangkum diketahui bahwa penjahit lebih banyak menggunakan mesin jahit dinamo dengan presentasi $72 \%$ daripada mesin jahit manual dengan presentasi $28 \%$. Kebanyakan penjahit mengeluh tentang tempat yang kurang memadai. Ruang yang kecil menjadi masalah dalam proses menjahit serta meletakan media penyimpanan. Saat ini yang digunakan oleh sebagian besar penjahit hanya laci-laci kecil yang tidak dapat menampung secara keseluruhan bahan jahitan, sedangkan kebutuhan seorang penjahit meliputi tempat benang dengan presentasi $63,3 \%$ laci penyimpanan alat menjahit $63,3 \%$, meja potong $70 \%$ meja jahit $63,3 \%$ setrika $50 \%$ dan alat lainnya yang presentasinya jauh lebih rendah.

Dari masalah di atas diharapkan dapat terciptanya sebuah meja jahit yang dapat difungsikan sebagai meja potong dan meja setrika pakaian yang sudah dijahit, terdapat pula ruang khusus untuk menyimpan peralatan menjahit seperti gunting, jarum, benang, kancing, resleting, meteran, buku catatan, pola dan lain-lain, serta terdapat sebuah ruang khusus untuk benang, dan jarum agar tidak lagi kusut atau patah. sehingga masalah di atas dapat di atas.

\section{Tahapan Desain}

Dalam mendesain produk ini, agar terarah ditetapkan tahapan-tahapan desain yang baku, dengan menggunakan metode Goel (1995), dengan tahapan sebagai berikut:

\subsection{Preliminery Desain}

Pengumpulan data dari informasi, analisis data berdasarkan konsep desain makro yang meliputi analisis konsep (konsep fungsi, konsep pemakaian,pemakain pasar, dan konsep produk), penyusunan program desain sketsa awal. Bagian diatas terdiri dari: 1) Perumusan Masalah, 2) Tinjauan Pustaka, 3) Analisis dan Spesifikasi Desain, 4) Spesifikasi Desain, 5) Design Development.

\subsection{Final Desain dan Prototype}

Dibuat gambar-gambar yaitu gambar presentasi 3D dan gambar teknik (gambar tampak, potongan, gambar detail dan spesifikasi teknik produk). Tahapan selanjutnya adalah pembuatan komponen-komponen dilakukan assembling (exploded) atau perakitan sehingga menjadi produk (prototype). 
Vol. 6, No. 1, Oktober 2018

III. Pembahasan

3.1. Analisis Ergonomi dan Antropometri

Analisis anthropometri dilakukan guna mendapatkan dimensi atau ukuran produk yang sesuai dengan tubuh pemakai. Sedangkan analisis ergonomi dilakukan untuk meminimalkan resiko kesehatan dan keselamatan dalam produk yang dirancang. Dengan begitu efisiensi, kesehatan, keselamatan, dan kenyamanan dalam melakukan kegiatan menggunakan produk ini dapat maksimal.

Ergonomi diperlukan untuk membuat suatu produk guna memberikan kenyamanan pada pengguna. Dengan begitu efisiensi, kesehatan, keselamatan, dan kenyamanan dalam melakukan kegiatan menggunakan produk dapat maksimal. Berikut beberapa analisis ergonomi yang perlu diperhatikan pada produk yang dirancang :

Pada umumnya pada saat membuat pola, penjahit sering melakukan kegiatan membuat pola di lantai karena tidak adanya meja yang besar untuk membuat pola atau meja membuat pola terpisah dengan meja jahit sehingga dapat memenuhi ruangan. Kegiatan membuat pola di lantai tidaklah ergonomis, karena untuk membuat pola penjahit harus membungkukkan badannya, dan posisi duduk terutama pada kaki sering berpindah posisi. Jika hal ini dilakukan berulang-ulang maka dapat menimbulkan kelelahan dan masalah pada persendian tulang. Dengan demikian meja pola dan meja jahit akan difungsikan menjadi satu kesatuan, agar tidak terus menerus membuat pola di lantai, dengan begitu penjahit dapat mengurangi resiko kelelahan.

Pada produk meja ini akan diletakkan juga beberapa laci yang akan menjadi satu pada meja, sehingga penjahit tidak bolak-balik untuk mengambil peralatan yang biasa diletakkan dibeda tempat.

Bahan yang digunakan untuk membuat produk menggunakan bahan yang tidak berbahaya bagi pengguna, dan sedapat mungkin menghindari bentuk dan sudut- sudut yang tajam yang dapat melukai pengguna. Keamanan dan kenyamanan penggunaan alat-alat menjahit di utamakan agar tidak dapat digunakan oleh anak-anak.

Analisis Anthropometri dilakukan guna mendapatkan dimensi atau ukuran produk yang sesuai dengan tubuh penggunanya. Berikut beberapa data antropometri yang akan digunakan sebagai acuan :

\section{a. Menentukan tinggi meja}

Menentukan tinggi meja, menggunakan dimensi tinggi lutut wanita dan disesuaikan dengan fungsi produk untuk bekerja sambil berdiri. Pada dimensi ini menggunakan ukuran tinggi siku pada posisi duduk 95\% wanita yaitu $295 \mathrm{~mm}$ ditambah dengan ukuran tinggi lipat lutut $95 \%$ wanita yaitu $425 \mathrm{~mm}$. Maka ukuran dari tinggi meja adalah $720 \mathrm{~mm}$ dan ditambah dengan toleransi tempat penyimpanan mesin jahit $30 \mathrm{~mm}$. Dari ukuran diatas maka ditentukan ukuran meja adalah $750 \mathrm{~mm}$ sehingga kaki tidak akan tersangkut saat bekerja.

\section{b. Menentukan kelonggaran ruang} meja bagian dalam

Menentukan tinggi meja bagian dalam saat digunakan pada posisi duduk menggunakan dimensi tinggi lipat lutut dengan 50 percentile wanita yaitu 375 $\mathrm{mm}$ dan tebal paha dengan 50 percentile wanita yaitu $130 \mathrm{~mm}$. Dan dari ukuran keseluruhan adalah $505 \mathrm{~mm}$. Data ini merupakan ukuran minimal untuk kelonggaran ruang meja. Kelonggaran ruang meja pada perancangan ini adalah $550 \mathrm{~mm}$, dengan demikian dalam membuat tinggi laci adalah sisa dari perhitungan tinggi meja - kelonggaran meja $=700 \mathrm{~mm}-550 \mathrm{~mm}=150 \mathrm{~mm}$

c. Menentukan lebar meja bagian dalam

Menentukan lebar meja bagian dalam saat digunakan pada posisi duduk menggunakan dimensi yang lebar panggul dengan 95 percentile wanita yaitu $365 \mathrm{~mm}$ dan ditambah toleransi 235 mm jadi keseluruhan ukuran untuk me- 
Darius Shyafari, Ameliya Mamesah, Desain Sarana Kerja Menjahit

nentukan lebar meja bagian dalam adalah $600 \mathrm{~mm}$.

Dimensi ini digunakan agar pengguna dapat leluasa dalam menggunakan produk tanpa harus kekurangan ruangan walaupun terdapat laci di samping meja tersebut.

\section{d. Menentukan panjang meja}

Ukuran panjang meja ini menggunakan antropometri jarak bentang tangan dari ujung jari tangan kanan ke kiri dengan jenis ukuran rata-rata wanita yaitu 1480 $\mathrm{mm}$, dan ditambah toleransi utk fungsi tambahan jenis pekerjaan membuat pola $120 \mathrm{~mm}$. Jadi ukuran panjang meja adalah $1600 \mathrm{~mm}$. Sehingga pengguna memiliki area yang lebih luas untuk memotong dan membuat pola diatas meja.

e. Menentukan lebar meja dan jarak jangkauan tangan ke display benang Untuk menentukan ukuran lebar meja dan jarak jangkauan tangan ke display benang perlu menggunakan jarak genggaman tangan ke punggung pada posisi tangan ke depan. Ukuran yang digunakan adalah ukuran minimum rata-rata wanita yaitu ukuran maksimal $635 \mathrm{~mm}$. Dimensi ini juga digunakan untuk menentukan jangkauan tangan bagi pengguna produk agar tidak susah ketika akan menjangkau benda yang ada di meja. Maka dari ukuran di atas diambil ukuran $600 \mathrm{~mm}$ karena sudah dapat memenuhi kebutuhan produk.

f. Menentukan panjang tangan ke bawah pada posisi duduk

Untuk menentukan ukuran jangkauan tangan pada laci ukuran panjang tangan ke bawah pada posisi duduk yang didapat dengan menjumlahkan data tinggi siku pada posisi berdiri dikurang dengan tinggi lipat lutut ditambah dengan tinggi siku pada posisi duduk dengan jumlah $790 \mathrm{~mm}$ dan dikurangkan lagi dengan ukuran tinggi genggaman tangan pada posisi relaks, jadi $790 \mathrm{~mm}-$ $715 \mathrm{~mm}$ didapatkan hasil dari penjum- lahan dengan ukuran 50\% wanita yakni $75 \mathrm{~mm}$.

Ukuran tersebut digunakan untuk mempermudah menjangkau laci-laci pada meja, sehingga pengguna tidak akan mengalami kesulitan dalam mencari barang/peralatan yang tersimpan pada laci bawah.

\subsection{Analisis Konfigurasi}

Analisis konfigurasi dilakukan guna mendapatkan bentukan atau susunan dari tiap- tiap komponen yang terdapat pada produk. Adapun komponen yang terdapat pada produk adalah: 1) Meja jahit, Meja pola dan setrika, 2) Tempat penyimpanan buku catatan, pensil, meteran Pola, kapur dan Penggaris, 3) Tempat penyimpanan karet, kancing, resleting, jarum dan gunting, 4) Tempat penyimpanan benang, 5) Tempat penyimpanan kain, 6) Tempat penyimpanan alat setrika

Pada analisis konfigurasi terdapat beberapa tempat penyimpanan. Dengan fungsinya masing masing yakni terdapat 3 laci untuk menyimpan peralatan menjahit lengkap dengan alat setrika, 1 buah lemari kecil untuk menyimpan kain dan 1 buah gantungan benang terpisah yang tepat berada diatas meja utama, serta terdapat juga meja lipat khusus untuk membuat atau memotong pola dan bisa juga digunakan sebagai meja setrika dan terdapat tempat yang berada disamping kanan meja.

Berdasarkan analisis terhadap komponen meja jahit yang telah dilaksanakan, maka konfigurasi yang tepat adalah konfigurasi pada gambar 1. Karena konfigurasi ini menempatkan peletakkan peralatan menjahit yang lebih efesien. Pada analisis konfigurasi dalam gambar 1 juga terdapat beberapa tempat penyimpanan. Dengan fungsinya masing masing yakni Terdapat 2 laci untuk menyimpan peralatan menjahit lengkap 1 buah lemari kecil untuk menyimpan kain yang menyatu dengan penyimpanan setrika dan, 1 buah gantungan benang yang terpisah dengan meja utama,dan juga terdapat meja 
Vol. 6, No. 1, Oktober 2018

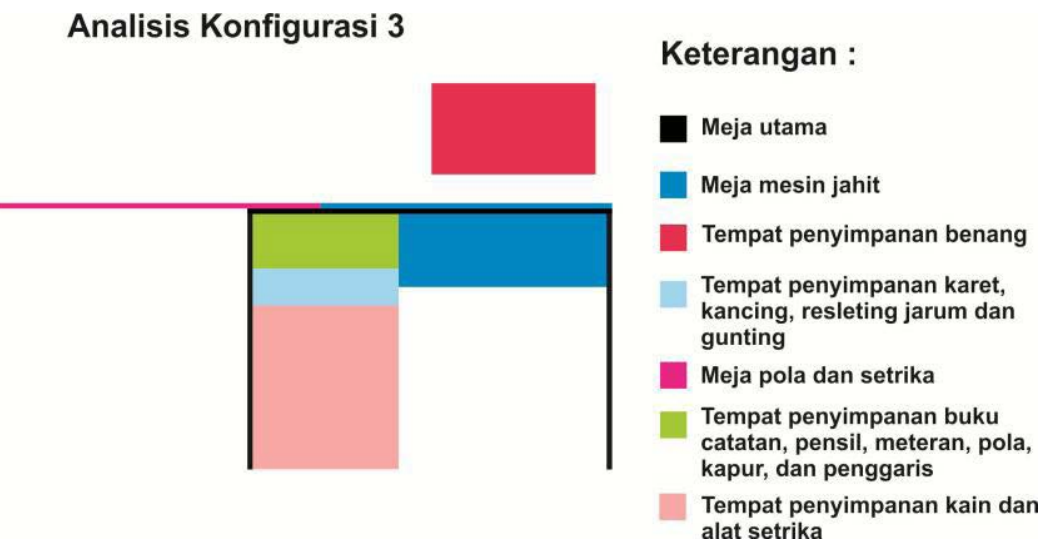

Gambar 1. Alternative konfigurasi terpilih

lipat khusus untuk membuat atau memotong pola dan bisa juga digunakan sebagai meja setrika.

\subsection{Analisis Bentuk}

Analisis bentuk diperlukan guna mendapatkan bentuk yang sesuai dengan konsep yang diambil. Dengan konsep desain modern ada beberapa bentuk cocok digunakan pada produk antara lain De Stijl, Konstruktivisme, atau Bauhaus. Dari gaya-gaya desain yang telah ditentukan akan terpilih satu gaya desain yang akan diaplikasikan pada produk berdasarkan kebutuhan pengguna atau target konsumen yang berusia 46 tahun.

Dari gaya desain De Stijl diketahui bahwa gaya tersebut memiliki ciri dengan kombinasi warna-warna primer seperti merah, biru dan kuning sedangkan pengguna produk atau target konsumen berusia 46 tahun yang membutuhkan warna-warna simple dan tidak mencolok agar pekerjaan menjahit tidak terganggu karena masalah warna yang tidak sesuai. Untuk gaya desain konstruktivisme memiliki ciri khas bentuk abstrak atau non objektif, memiliki susunan atau komposisi geometris yang sederhana, akan tetapi terdapat kesulitan untuk menemukan bentuk yang sesuai dengan produk, sedangkan untuk bentuk bauhaus lebih cenderung berbentuk goemetris murni dan menyajikan bentuk-bentuk polos dan jujur bahan dan cocok untuk diaplikasikan pada produk.

Sehingga produk yang akan dibuat dengan gaya desain Bauhaus yang berbentuk persegi sederhana, karena persegi itu sendiri dapat dirangkai, memiliki ruang yang luas, dan memiliki makna stabilitas, kesetaraan, dan kejujuran. Persegi juga merupakan simbol ketegasan, kepastian, keseriuasan, kokoh dan tidak goyah dan sesuai dengan karakter pengguna yang menginginkan bentuk yang simple dan sederhana.

\subsection{Analisis Sistem}

Analisis sistem dilakukan guna menentukan sistem yang baik yang akan digunakan pada produk. Berdasarkan hasil analisis konfigurasi terdapat beberapa komponen yang membutuhkan sistem adapun bagian-bagian tersebut adalah :

\section{a. Meja Utama}

Meja utama memerlukan beberapa sistem yang akan diaplikasikan secara khusus berdasarkan fungsinya. Dari hasil analisis, terpilih sifat konstruksi yang akan digunakan pada meja utama yaitu konstruksi yang bersifat permanen/Fixed Construction, karena meja utama adalah komponen yang menopang komponen lainnya, sehingga konstruksi yang digunakan harus lebih kuat. Dari analisis di atas sistem konstruksi yang akan digunakan pada meja utama adalah konstruksi konfensional, karena meja utama akan dibuat secara permanen dan tidak 
Darius Shyafari, Ameliya Mamesah, Desain Sarana Kerja Menjahit

dapat dibongkar pasang sehingga kekuatan dari produk akan lebih terjaga. System sambungan yang cocok untuk diapliksikan pada komponen meja utama yaitu sistem sambungan butt joints yang menggunakan secrup sebagai pengunci dari sistem sambungan untuk menyambungakan sisi-sisi potongan yang akan membentuk sebuah meja.

\section{b. Meja Mesin Jahit}

Meja mesin jahit memerlukan beberapa sistem yang akan diaplikasikan secara khusus berdasarkan fungsinya. Dari hasil analisis terpilih sifat konstruksi yang akan digunakan pada meja mesin jahit adalah konstruksi semi permanen, karena meja mesin jahit akan difungsikan sebagai tempat penyimpanan mesin jahit ketika tidak terpakai sehingga pada analisis sistem akan menggunakan sistem engsel yang akan dijelaskan pada analisis selanjutnya.

Dalam komponen meja mesin jahit dibutuhkan engsel kupu-kupu yang akan diaplikasikan untuk tempat penyimpanan mesin jahit. Sehingga lebih mudah ketika akan menyimpan mesin jahit ketika tidak digunakan.

\section{c. Tempat Penyimpanan Benang}

Tempat penyimpan benang memerlukan beberapa sistem yang akan diaplikasikan secara khusus berdasarkan fungsinya. Dari hasil analisis terpilih konstruksi permanen agar lebih kuat untuk menampung benangbenang yang akan digantung pada tempat penyimpanan tersebut.

Dari hasil analisis terpilih sistem sekrup gantung tanda tanya full yang akan diaplikasikan pada tempat penyimpanan benang agar lebih mudah ketika ingin menggantung tempat penyimpanan pada dinding.

\section{d. Laci Tempat Penyimpanan peralatan menjahit}

Tempat penyimpan peralatan menjahit yang ada pada analisis konfigurasi terbagi menjadi dua bagian dengan fungsi yang sama dan sesuai dengan aktivitas yang akan dilaku- kan seorang penjahit sehingga memerlukan beberapa sistem yang akan diaplikasikan secara khusus berdasarkan fungsinya. Konstruksi yang akan digunakan pada komponen tempat penyimpanan peralatan menjahit adalah konstruksi kontemporer karena komponen tersebut akan dibuat dengan sifat semi permanen, agar lebih mudah dalam pengoprasian komponen tersebut.

System sambungan joint connecting bold digunakan pada komponen tempat penyimpanan peralatan menjahit karena lebih kuat dan lebih mudah dalam proses pengerjaannya. Sistem rel laci yang terpilih untuk komponen tempat penyimpanan peralatan menjahit adalah rel laci jenis doubletrack lebih kuat dan mudah dalam pengoprasian pada produk.

\section{e. Meja Pola dan Setrika}

Meja pola dan setrika pada produk ini akan dibuat menjadi satu tempat yang memiliki 2 fungsi berbeda sehingga memerlukan beberapa sistem. Konstruksi yang akan digunakan pada meja pola dan setrika adalah konstruksi semi permanen karena akan memudahkan aktivitas pengguna. System konstruksi yang akan digunakan pada komponen meja setrika dan pola adalah konstruksi kontemporer karena komponen tersebut akan dibuat semi permanen. System engsel yang akan digunakan pada meja pola dan setrika adalah sistem engsel kupu-kupu karena mudah didapatkan dan harganya cukup terjangkau serta tebih mudah dalam pengerjaannya.

\section{f. Tempat Penyimpanan Kain dan Alat Setrika}

konstruksi yang akan digunakan pada penyimpanan kain dan alat setrika adalah konstruksi semi permanen karena akan lebih mudah dalam pengoprasiannya. System sambungan yang akan digunakan pada tempat penyimpanan kain dan alat setrika adalah sistem sambungan joint connecting bolt, karena lebih kuat dan lebih mudah dalam pengerjaan. System engsel yang akan digunakan pada tempat penyimpanan kain 
Vol. 6, No. 1, Oktober 2018

dan alat setrika adalah sistem engsel sendok karena akan lebih mudah menutup dan tidak mudah terbuka sehingga lebih cocok untuk diaplikasikan pada komponen tempat penyimpanan kain dan alat setrika.

\subsection{Analisis Material}

Analisis material dilakukan guna menentukan material yang baik yang akan digunakan pada produk. Produk akan dibuat dengan sistem konstruksi tanpa menggunakan rangka dan material yang akan digunakan adalah jenis material kayu olahan yang diharapkan dapat membuat produk lebih kuat, tahan lama dan tidak mudah lapuk. Pemilihan material juga harus di pertimbangkan seperti harga material yang murah, kuat, mudah di dapatkan dan ringan Berikut adalah analisis dari material utama yang memakai bahan alami buatan :

Dari beberapa analisis material utama yang akan diaplikasikan pada produk adalah kayu olahan jenis plywood. Plywood ini dipilih karena memiliki kekuatan dan ketahanan yang cukup baik serta lebih tahan air dan lembab, dan memiliki kerapatan struktur yang baik, mudah dibentuk, dan penyebarannya yang mudah ditemui di daerah Samarinda.

Dalam perancangan produk ini juga membutuhkan tambahan ornamen yang akan di aplikasikan pada produk agar dapat menciptakan kesan modern, mewah dan elegan yang terbuat dari bahan non alami. Pemilihan material sebagai tambahan ornamen ini juga berdasarkan kekuatan, harga yang relatif murah, mudah didapatkan, ringan, dan pengerjaannya yang mudah.

Dari beberapa analisis material tambahan yang akan digunakan ada dua jenis yang yaitu material stainless yang digunakan sebagai ornamen pada meja yang menggantikan posisi kaki meja. Stainless ini dipilih karena memiliki kekuatan dan ketahanan yang cukup baik serta lebih tahan air dan tidak mudah berkarat, dan cocok sebagai ornamen dari produk yang akan dibuat agar dapat menimbulkan kesan mewah, elegan dan modern.

Selain itu terpilih juga material alumunium yang akan digunakan sebagai tempat benang karena harganya yang terjangkau dan mudah dalam pengerjaan serta lebih ringan sehingga cocok untuk digunakan sebagai material untuk membuat tempat benang.

Pemilihan material finishing juga dibutuhkan untuk memperindah hasil akhir dari produk yang akan didesain dengan kriteria yang modern, kuat, mudah didapatkan, pengerjaanya yang mudah serta harga yang murah sangat dibutuhkan pada analaisis material finishing, berikut analisisnya :

Dari analisis sistem finishing terpilih sistem lapisan HPL yang akan diaplikasikan untuk produk karena lebih mudah diaplikasikan serta sesuai dengan konsep dan cukup kuat untuk melapis permukaan produk selain itu ketersedian bahan banyak dan harganya cukup terjangkau sehingga lapisan HPL cocok untuk produk. Hanya saja pada bagian sisi-sisi dan ujung HPL sedikit tajam yang menjadi kekurangan dari HPL sehingga dibutuhkan lapisan bevel berbahan dempul pada sisi-sisi yang tajam agar tidak melukai pengguna.

\subsection{Analisis Warna}

Analisis warna diperlukan guna mendapatkan warna yang sesuai dengan konsep yang diambil. Adapun warna-warna yang memungkinkan diaplikasikan pada produk adalah warna-warna netral. Yang berhubungan dengan gaya desain Bauhaus.

Dari hasil analisis, warna cokelat dan putih akan diaplikasikan pada produk Analisis warna ini dilakukan dalam dua jenis yakni pemilihan warna sebagai aksen dan warna yang akan mendominasi produk tersebut. Warna pendominasi yang akan digunakan yaitu warna putih karena warna putih dapat memberikan kesan bersih, ringan, dan terang serta di yakini dapat menimbulkan kesan kekuatan pada produk tersebut. Sedangkan untuk warna aksen menggunakan warna cokelat yang identik 
Darius Shyafari, Ameliya Mamesah, Desain Sarana Kerja Menjahit

dengan stabilitas dan kehangatan serta dapat menciptakan rasa nyaman dan aman bagi produk itu sendiri. Sehingga kedua warna ini dikombinasikan akan memberikan kesan yang bersih, terang, nyaman dan menimbulkan kesan hangat, aman dan stabil.

\subsection{Proses Desain Altematif}

Langkah awal dalam mendesain adalah membuat beberapa alternative desain. Alternative-alternatif desain ini selanjutnya dianalisis sesuai kriteria desain yang telah ditentukan. Dari beberapa alternative yang ada terpilih alternatif desain yang ditunjukkan dalam gambar 2 dan 3 .

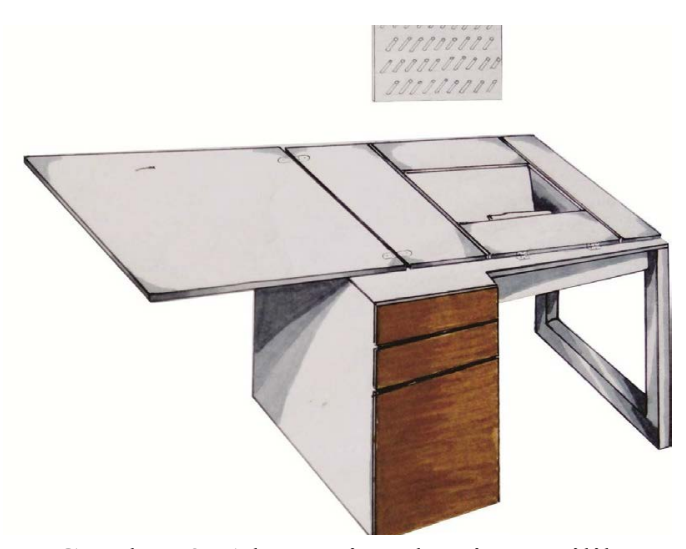

Gambar 2. Alternative desain terpilih

Tempat penyimpanan buku catatan pensil, meteran, pola, kapur dan penggaris

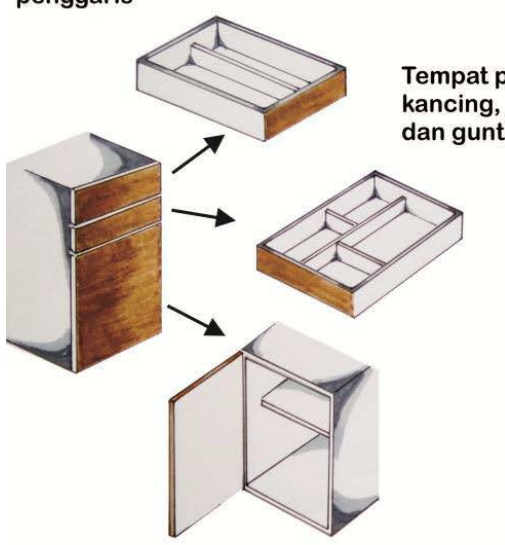

Tempat penyimpanan kain dan alat setrika

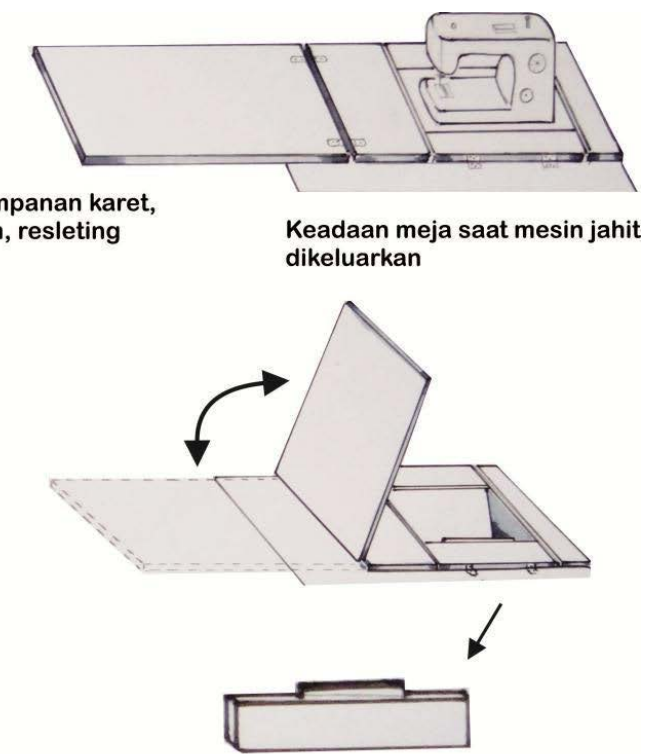

Sebagai penahan mesin saat di keluarkan

Gambar 3. Alternatif desain terpilih 
Dari alternative desain awal terpilih di atas, selanjutnya dikembangkan lagi menjadi beberapa alternative desain pengembangan. Pengembangan ini dilakukan agar bisa disesuaikan dengan kondisi industry agar bias diproduksi masal.

Dari beberapa alternative desain pengembangan, terpilih desain pengembangan seperti ditunjukkan dalam gambar 4 dan 5. Selanjutnya diselesaikan dalam desain final, yang dapat dilanjutkan ke dalam tahap produksi, berupa prototype produk.

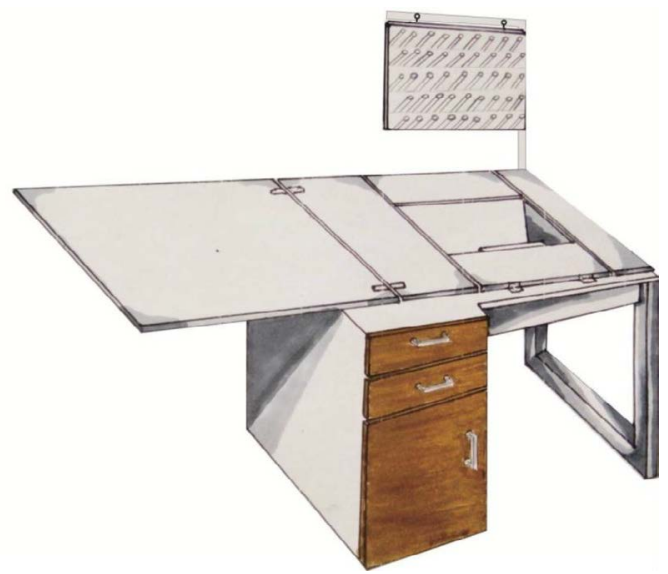

Gambar 4. Desain pengembangan terpilih

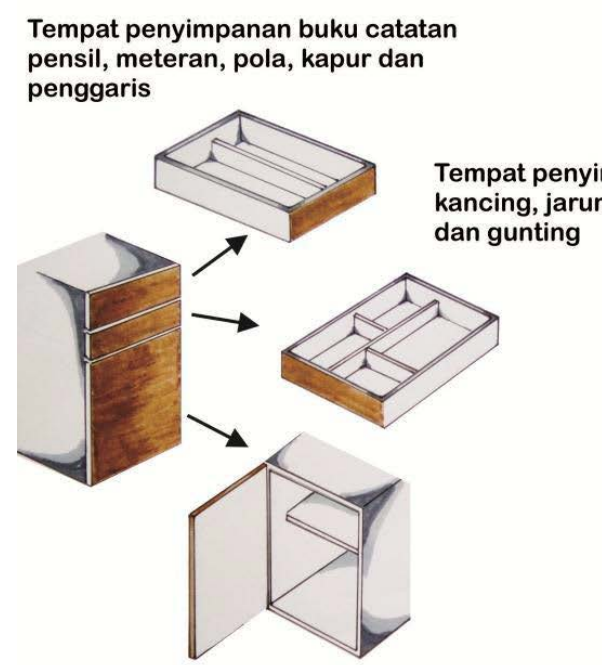

Tempat penyimpanan kain dan alat setrika

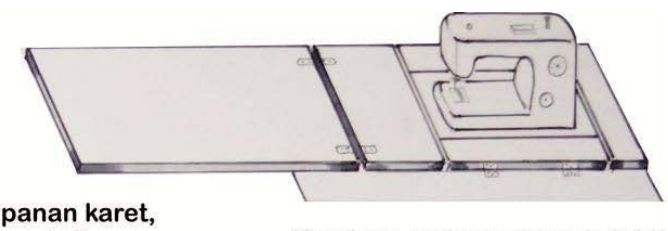

Keadaan meja saat mesin jahit dikeluarkan

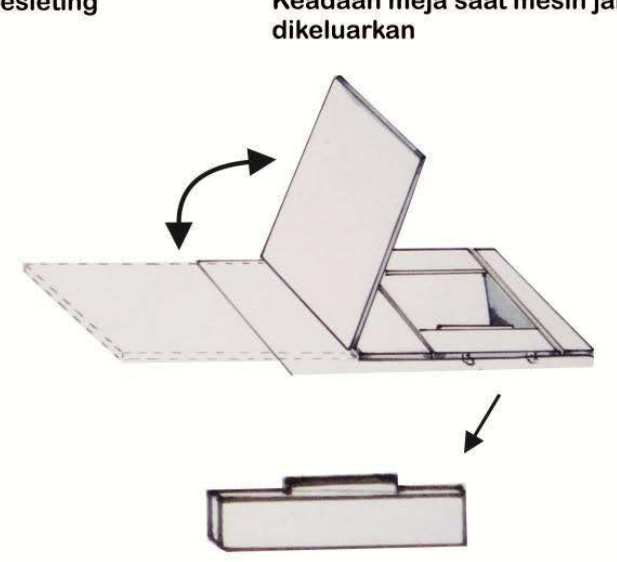

Sebagai penahan mesin saat di keluarkan

Gambar 5. Desain pengembangan terpilih 
Darius Shyafari, Ameliya Mamesah, Desain Sarana Kerja Menjahit

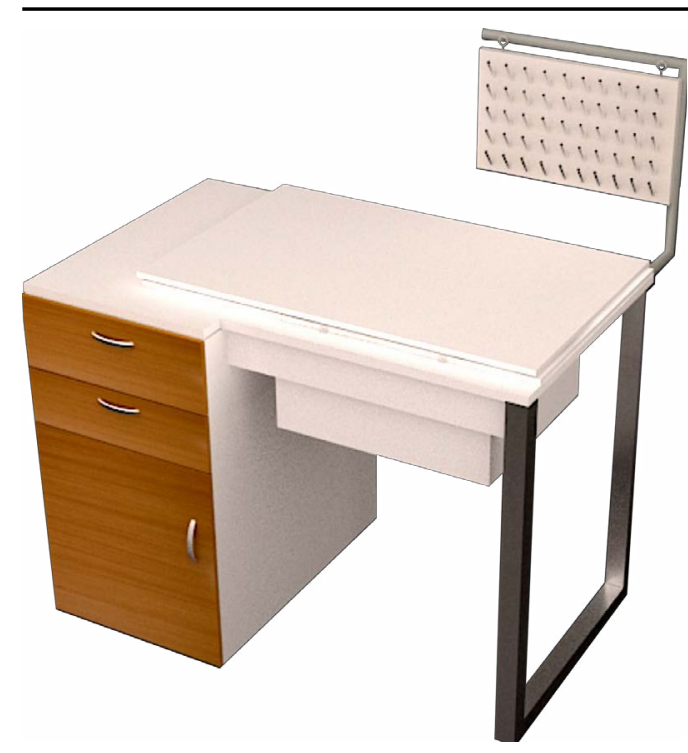

Gambar 6. Gambar presentasi

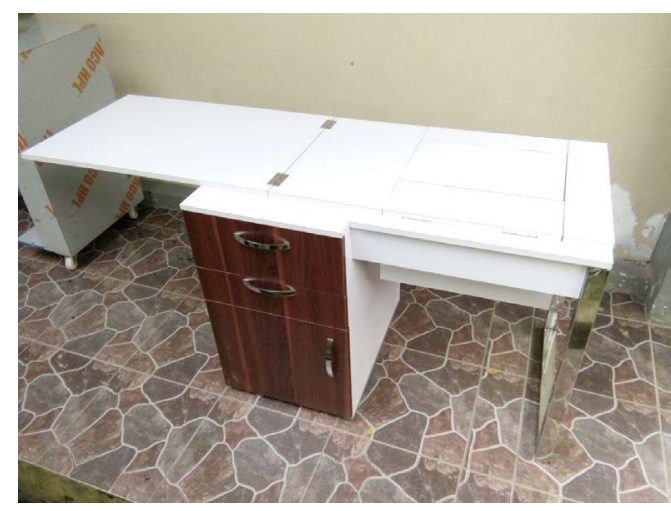

Gambar 7. Prototipe produk

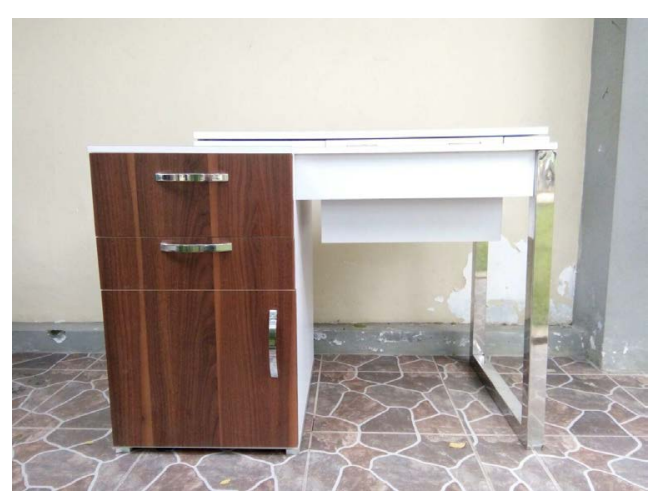

Gambar 9. Prototipe produk

\section{Kesimpulan}

Simpulan dari hasil perancangan Desain Sarana Kerja Menjahit ialah sebagai berikut: Menyediakan sarana kerja untuk penjahit dengan tempat penyimpanan peralatan menjahit dan meja lipat untuk membuat pola dan menyetrika yang sudah menjadi satu kesatuan dengan meja utama agar mempermudah penjahit dalam bekerja. Desain Sarana kerja menjahit ini didesain dengan sistem yang sederhana dan mudah dioprasionalkan serta dapat menampung berbagai aktvitas penjahit Desain Sarana kerja menjahit ini dapat difungsikan dalam ruang kecil.

Saran yang dapat diberikan bagi para produsen dan desainer adalah menganalisa kembali aktivitas dalam penggunaan produk, sehingga kebutuhan- kebutuhan akan elemen desain yang memudahkan aktivitas dapat dipenuhi dan dengan ditambahnya fungsi produk yang menjadi satu kesatuan yang tepat dan sesuai aktivitas, sehingga menambah daya tarik konsumen. Selain itu diharapkan adanya perancangan lanjutan mengenai material dan dimensi yang telah dibuat, dan penambahan fungsi yang dapat dimasukan kedalam produk, sehingga produk akan menjadi lebih baik. 
Vol. 6, No. 1, Oktober 2018

DAFTAR RUJUKAN

Eddy S.Marizar. (2005). Designing Furniture (Teknik Merancang Mebel Kreatif Kristianto. M. Gani. (1993). Tehnik Mendesain Perabot yang Benar.Yogyakarta: Kanisius Sunarya, Yan yan. (2000) Sejarah Seni Rupa dan Desain Modern, Bandung: Institut Wignjosebroto, Soetandyo. (2003). Ergonomi Dalam Teknik Industri. Surabaya: Bayuwangi.

\section{Webtografi}

Bisniskonfeksi. (2017). Jenis-jenis mesin jahit dan fungsinya. http://Bisniskonfeksi.com./ jenis-jenis-mesin-jahit/. (22 November, 2017).

Erniati, D.A. (2014). Mengenal Empat Jenis Kayu Olahan. http://www.derumi. net/2014/02/mengenal-jenis-kayu-olahan-bahan- furniture.html. 23 Oktober 2017.

Heritage, Singer. (1875) Mesin Jahit Singer. http://www.singerhomeindonesia.com/index. php/22-blog-posts/63-mesin-jahit- singer. 20 Juli 2017.

Salamadian, (2017). 13 Arti Warna dan Psikologi Warna. Januari 14, 2017. http://Salamadian.com/Artiwarna/-.

Winsen. (2016). 21 Teknik Dasar Menjahit Bagi Pemula. https://ilmuseni.com/seni- rupa/ kerajinan-tangan/teknik-dasar-menjahit. 22 November 2017.

Www.Dekoruma.com/artikel/furniture101. Metal, Si Kuat dan Awet. (1 Agustus 2016). 